\title{
Studying Identities with Experiments: Weighing the Risk of Posttreatment Bias Against Priming Effects - Corrigendum
}

Samara Klar, Thomas Leeper and Joshua Robison

DOI: https://doi.org/10.1017/XPS.2019.26, published online 11 October 2019

In the original publication of Klar et al. (2019), an error appeared in Table 1 . The correct Table 1 is reproduced below:

Table 1

A Framework for Measurement Order Decisions

\begin{tabular}{|c|c|c|}
\hline $\begin{array}{l}\text { Qualities of covariate and treatment, } \\
\text { as determined by the researcher }\end{array}$ & $\begin{array}{l}\text { Pretreatment } \\
\text { Measure }\end{array}$ & Posttreatment measure \\
\hline i. Covariate is fixed/stable & $\begin{array}{l}\text { Risk of priming } \\
\text { effects }\end{array}$ & OK \\
\hline $\begin{array}{l}\text { i. Covariate is susceptible to treatment } \\
\text { ii. Covariate cannot contaminate study via } \\
\text { priming effects }\end{array}$ & OK & Risk of posttreatment bias \\
\hline $\begin{array}{l}\text { i. Covariate is not susceptible to } \\
\text { treatment } \\
\text { ii. Covariate can contaminate study via } \\
\text { priming effects }\end{array}$ & $\begin{array}{l}\text { Risk of priming } \\
\text { effects }\end{array}$ & $\mathrm{OK}$ \\
\hline $\begin{array}{l}\text { i. Covariate is susceptible to treatment } \\
\text { ii. Covariate can contaminate study via } \\
\text { priming effects }\end{array}$ & $\begin{array}{l}\text { Risk of priming } \\
\text { effects }\end{array}$ & Risk of posttreatment bias \\
\hline
\end{tabular}

\section{Reference}

Klar, S., Leeper, T., \& Robison, J. (2019). Studying Identities with Experiments: Weighing the Risk of Posttreatment Bias Against Priming Effects. Journal of Experimental Political Science, doi: 10.1017/ XPS.2019.26 